\title{
MY018A Gene
}

National Cancer Institute

\section{Source}

National Cancer Institute. MYO18A Gene. NCI Thesaurus. Code C98026.

This gene is involved in cytoskeletal structure. 